\title{
Processos Costeiros Condicionantes do Litoral Brasileiro
}

\author{
Moysés Gonsalez Tessler ${ }^{1}$ \\ Samara Cazzoli y Goya ${ }^{1}$
}

\begin{abstract}
Resumo: Este texto aborda a ação dos processos existentes na costa brasileira como agentes condicionantes dela. Inicia-se esta abordagem com o estudo da herança geológica, da variação do nível do mar e da ação da dinâmica atual na modelagem das planícies costeiras. A seguir, é estudada a compartimentação do litoral brasileiro, descrevendo sucintamente os diferentes segmentos costeiros e por fim, é abordado o tema de erosão costeira. Nesta parte são estudadas causas naturais e antropogênicas, com avaliação de alguns casos ao longo do litoral brasileiro. Como conclusão, é feita uma breve descrição da compatibilidade entre a evolução geológica e histórica dos ambientes costeiros com a necessidade de ocupação do litoral.
\end{abstract}

Palavras-chave: Sistemas costeiros; Dinâmica costeira atual, Herança geológica, Variação do nível relativo do mar.

\section{Origem e Caracterização Geomorfológica dos Atuais Sistemas Costeiros Brasileiros}

Todos os jornais atualmente trazem, pelo menos uma vez ao dia, notícias sobre a região litorânea, apontando para a exploração de gás e petróleo na plataforma continental, para a ocupação (organizada ou não) do solo, para o potencial turístico e para os recursos naturais do litoral brasileiro.

E não é sem razão que esta ênfase toda seja dada ao litoral brasileiro. Ele compreende mais de $8000 \mathrm{~km}$ de extensão, abrangendo os mais variados tipos de sistemas costeiros como praias arenosas, falésias ígneas e sedimentares, estuários, dunas e manguezais. Estas variadas paisagens possuem valor incalculável e são muitas vezes ameaçadas em sua estabilidade por intervenções antropogênicas ou por causas naturais associadas a variações climáticas e, conseqüentemente, a variações relativas do nível do mar.

A responsabilidade de formação e manutenção desta ampla linha de costa é prioritariamente associada a três fatores, que atuaram e atuam em várias escalas temporais e espaciais: a herança geológica, o modelado quaternário e a ação da dinâmica sedimentar atual.

\section{Herança Geológica}

A configuração do litoral brasileiro, tanto em relação à sua posição geográfica quanto em termos de orientação da linha de costa, resultou, em grande parte, da reativação pós-paleozóica que deu origem às bacias sedimentares tafrogênicas e à própria gênese do Oceano Atlântico. Para entender melhor este processo é necessário remontar à observação da história geológica ao fim do período Jurássico (há cerca de 150 milhões de anos), para

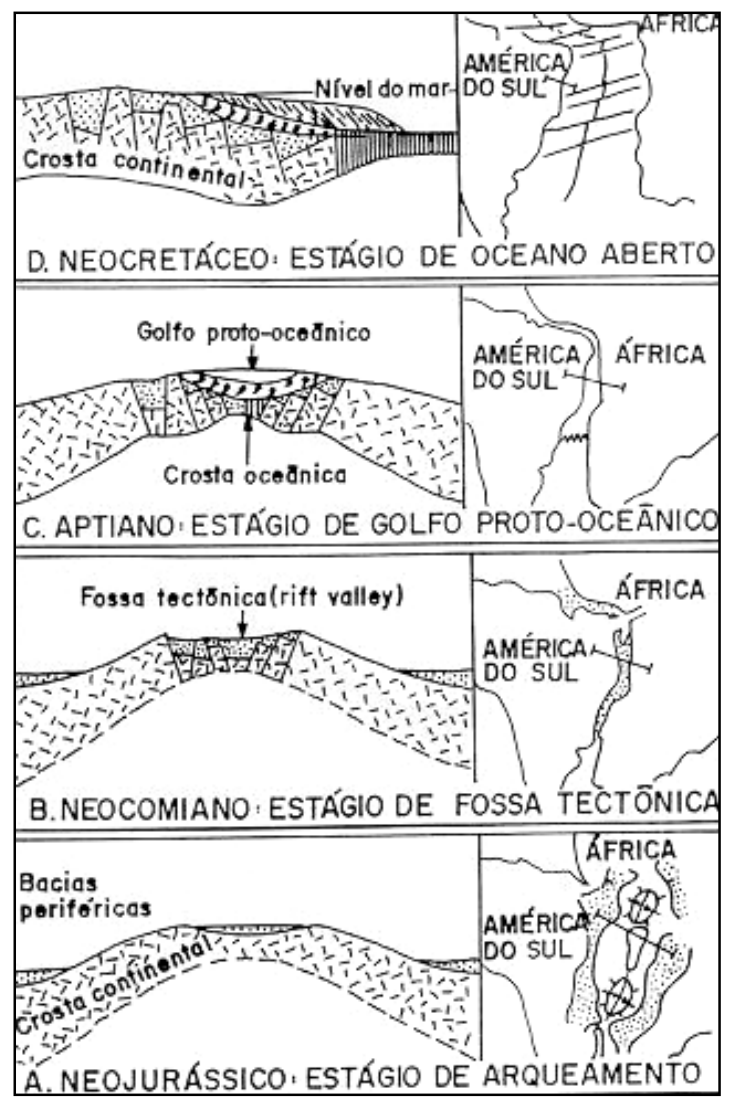

Figura 1 Abertura do Oceano Atlântico. Fonte: PONTE e ASMUS, 1978.

1 Instituto Oceanográfico da Universidade de São Paulo. mgtessle@usp.br, scgoya@terra.com.br. 
panhar a formação do que seria o atual litoral brasileiro desde seu início. Neste período, ocorreu a separação do super continente Gondwana acompanhada por eventos tectono-magmáticos. Estes são representados pela extrusão de magma alcalino e formação de bacias na área da atual margem continental como na área continental adjacente, sendo que todas estas bacias foram, posteriormente, preenchidas por sedimentos. Este evento foi denominado reativação pós-paleozóica (ALMEIDA e CARNEIRO, 1987). A Fig. 1 ilustra a formação do Oceano Atlântico entre o fim do período Jurássico e o fim do Cretáceo.

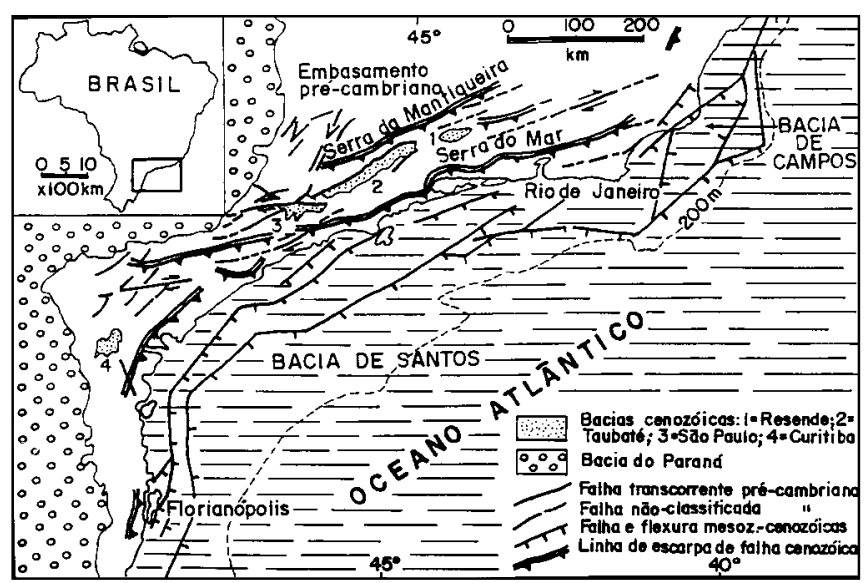

Figura 2 Arcabouço Tectônico do Sudeste Brasileiro. Fonte: ALMEIDA, 1976.
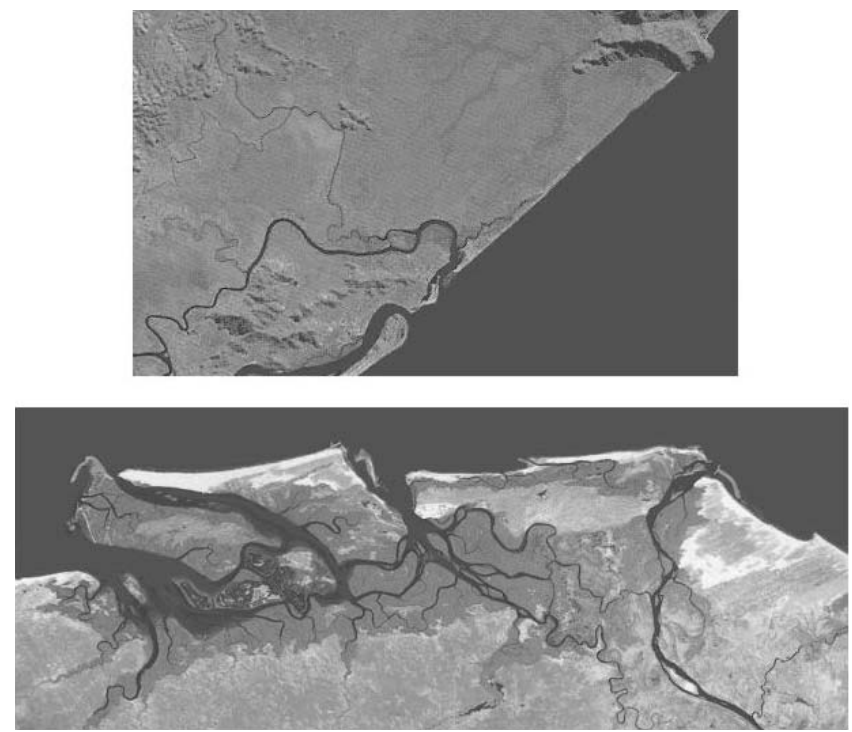

Figura 3 As duas principais direções existentes no litoral brasileiro. A Fig 3a ilustra a direção Brasiliana (NE-SE) na área de Iguape (SP) e a Fig. 3b ilustra a direção Caraíba (E-W) na área do litoral maranhense. Fonte: AB'SABER, 2001.

Os lineamentos estruturais como falhas e fraturas não apenas condicionaram a fragmentação do bloco Gondwânico originando a formação do Atlântico Sul, mas se mantêm impressos no relevo pelo condicionamento da disposição da rede de drenagem e da direção da linha de costa (Fig. 2).

As direções predominantes destas estruturas são basicamente duas: a direção denominada Brasiliana (nordeste / sudeste) e a direção Caraíba (noroeste / sudeste). Predomina a direção Brasiliana na região entre Chuí (RS) e Cabo Calcanhar (RN) e, a direção Caraíba entre Cabo Calcanhar (RN) e Oiapoque (AP) (Fig. 3a,b).

Afastamentos gradativos destas orientações principais são resultantes principalmente de condicionamentos associados às atividades tectônicas terciárias. Dentre estes, é mais proeminente a presença de zonas de fraturas oceânicas, como a do Rio de Janeiro, responsável pelo alinhamento de Leste a Oeste do litoral de Cabo Frio (Fig. 4).

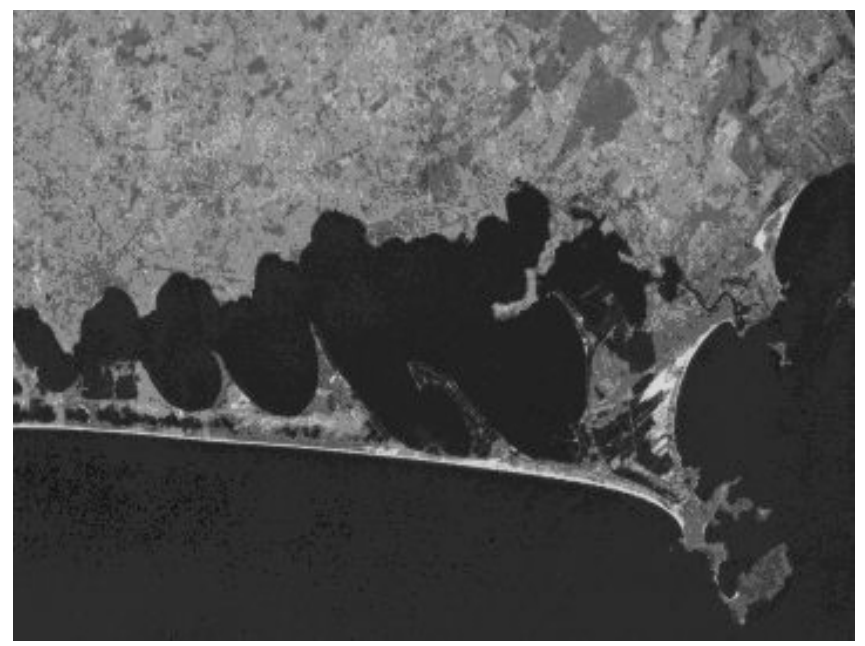

Figura 4 Alinhamento E-W da costa carioca entre Arraial do Cabo e Massambaba. Fonte: AB'SABER, 2001.

Alterações mais localizadas são dadas por progradação sedimentar como, por exemplo, as desembocaduras dos rios Amazonas, Jequitinhonha e São Francisco (Fig. 5) além de construções vulcânicas e biogênicas como as existentes na plataforma de Abrolhos (Fig. 6).

\section{Modelado quaternário}

As flutuações do nível relativo do mar constituem elemento importante na evolução das planícies costeiras brasileiras, sobretudo no Quaternário. Este fato foi descrito por diversos autores (HARTT, 1870; BRANNER, 1904; FREITAS, 1951; BIGARELLA, 1965) e em especial por SUGUIO e MARTIN (1978, 1985), Fig. 7. 


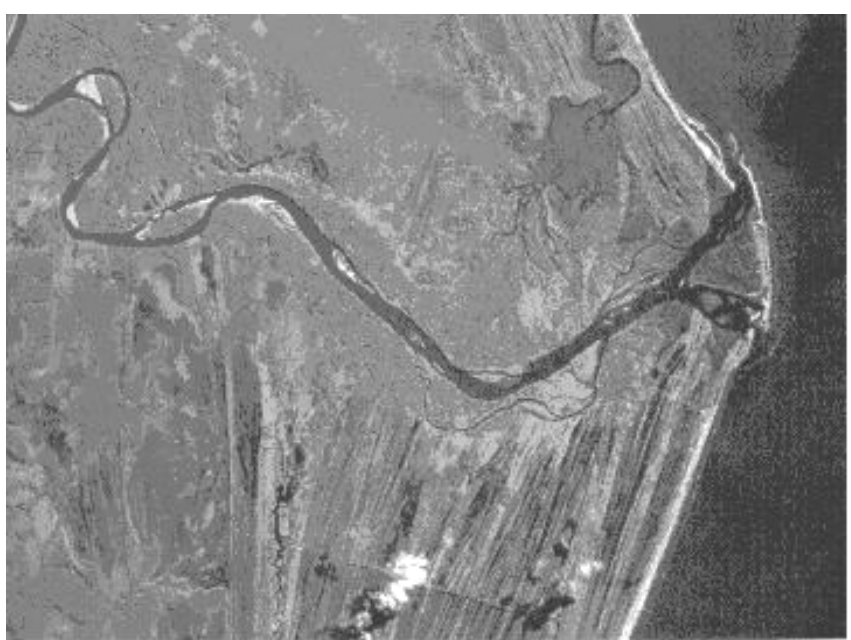

Figura 5 Desembocadura do Rio Jequitinhonha, litoral leste do Brasil. Fonte: AB'SABER, 2001.

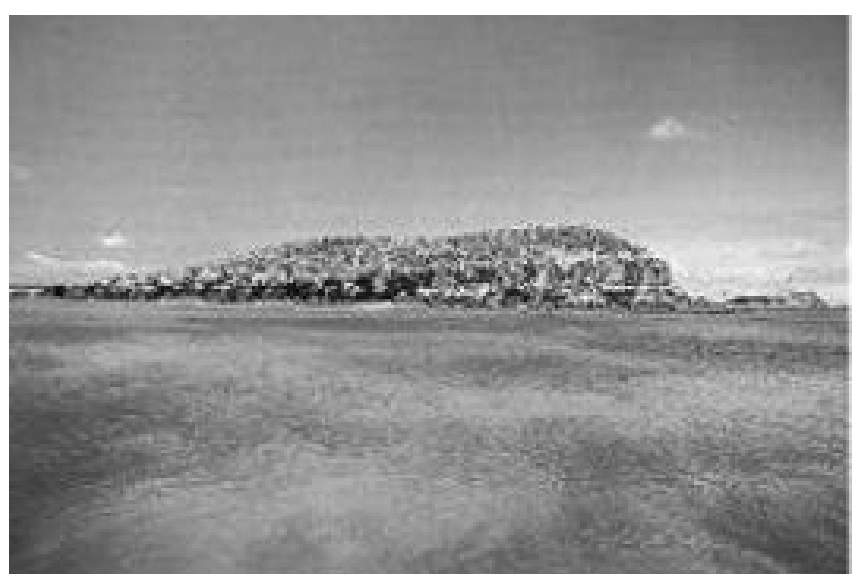

Figura 6 Afloramento vulcânico no arquipélago de Abrolhos. Fonte: www. portonet.com.br.

O registro mais completo da evolução das planícies costeiras é encontrado na planície costeira do Rio Grande do Sul. Nele foram identificados, a partir do fim do terciário, quatro ciclos transgressivo-regressivos (VILLWOOCK et al., 1986). Estes ciclos foram caracterizados com base em evidências sedimentares, biológicas e pré-históricas.

Na maioria das planícies costeiras brasileiras, as seqüências sedimentares presentes, com idades anteriores ao final do Terciário e Quaternário, são representadas pela Formação Barreiras e unidades correlatas.

Ao longo do Quaternário, dois ciclos transgressivos e regressivos modelaram as planícies costeiras brasileiras, conseqüência de oscilações relativas do nível do mar. 0 primeiro ciclo, de idade pleistocênica ( 120000 anos A.P.), atingiu cotas de $8 \pm$ 2 metros acima do nível atual. Este evento foi denominado como
Transgressão Cananéia no trecho da costa paulista (SUGUIO e MARTIN, 1978) ou Penúltima Transgressão no litoral dos estados do Rio Grande do Sul (VILLWOOCK et.al 1986), Bahia, Sergipe e Alagoas (BITTENCOURT et al., 1979). São encontrados registros por todo o litoral brasileiro entre os estados do Rio Grande do Sul e Paraíba sob a forma de terraços marinhos com constituição essencialmente arenosa.

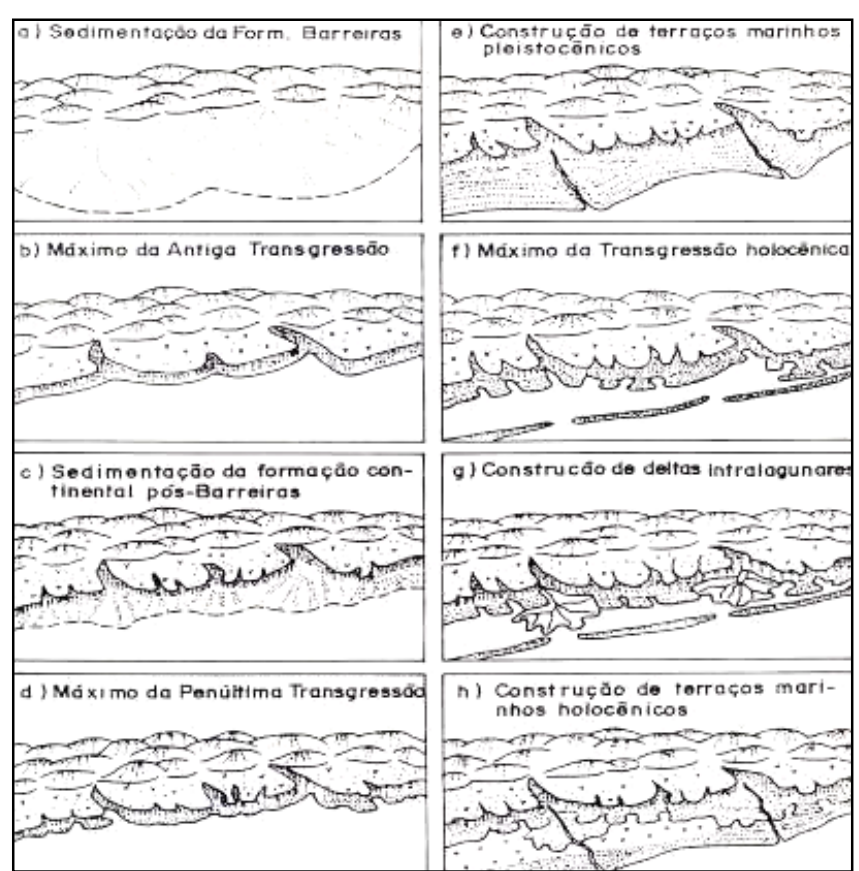

Figura 7 Evolução paleogeográfica de grande parte do litoral brasileiro desde o Terciário superior até hoje. Fonte: SUGUIO e MARTIN (1978).

A partir do máximo transgressivo pleistocênico, o nível do mar recuou até posições ao redor da isóbata de 110 metros abaixo do nivel atual, há cerca de 17000 anos A.P. Ao longo deste processo de regressão marinha, a atual plataforma continental foi quase totalmente exposta, sendo sulcada por vales fluviais.

Desta forma, ao longo do Pleistoceno, em cerca de cem mil anos (120000 - 17000 anos A.P.), ocorreu uma variação aproximada de 118 metros do nível relativo do mar. Neste período, de um modo simplista, verifica-se uma taxa média de variação relativa do nível do mar de $0,19 \mathrm{~cm} /$ ano.

A partir do máximo regressivo, o nível relativo do mar foi submetido a uma nova elevação, tendo atingido há cerca de 7000 anos A.P., um nível próximo do zero atual (SUGUIO e MARTIN, 1978). Este processo transgressivo se manteve até 5100 anos A.P., atingindo quatro metros acima do nível atual. Esta foi denominada para o litoral paulista de Transgressão Santos (SU- 
GUIO e MARTIN, 1978). Diferentemente do verificado nos terraços pleistocênicos, nos terraços holocênicos é encontrada grande quantidade de material passível de datação por carbono 14 ou termoluminescência.

SUGUIO et al. $(1985,1988)$ realizaram aproximadamente 700 datações de radiocarbono nos sedimentos destes terraços holocênicos. Isto permitiu construir uma curva de variação do nível do mar válida para vários pontos do litoral brasileiro (Fig. 8).

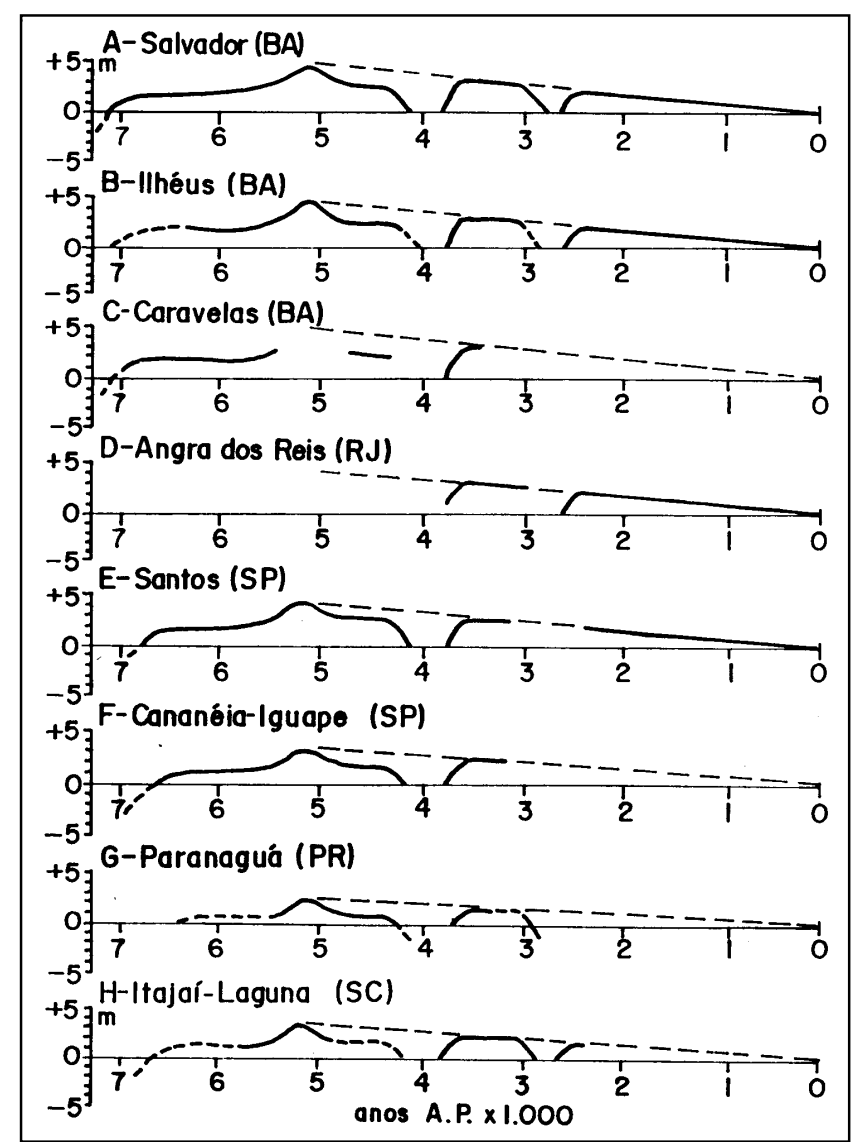

Figura 8 Nível do mar no litoral brasileiro. Fonte:SUGUIO et al., 1985.

Desta forma, pode-se admitir como uma aproximação, que a variação do nível do mar em 12000 anos (17000 - 5000 anos A.P.) foi de 114 metros, com uma taxa anual de variação positiva de $0,95 \mathrm{~cm} / \mathrm{ano}$.

Levadas em consideração somente a elevação e a posterior descida do nível do mar entre 7000 anos atrás e os dias atuais, a variação foi bem menos expressiva, em torno de 8 metros, com uma taxa anual de aproximadamente $0,1 \mathrm{~cm} / \mathrm{ano}$.

\section{Ação da Dinâmica Sedimentar Atual}

A dinâmica sedimentar atual responde pelas variações da linha de costa, quer sejam de caráter momentâneo, quer sejam indicativa de tendência sedimentar de um determinado segmento costeiro. Esta dinâmica é regida principalmente por dois condicionantes oceanográficos: o clima de ondas e o regime de marés.

\section{Clima de Ondas}

"A principal variável indutora dos processos costeiros de curto e de médio prazo é o clima de ondas, responsável pelo transporte nos sentidos longitudinal e transversal à linha de costa" (MUEHE, 1998). É a energia das ondas, a intensidade e a recorrência das tempestades que comandam a dinâmica dos processos de erosão e acumulo na interface entre continente e oceano. O clima de ondas é determinado pela ação dos ventos originados no Atlântico Sul (Fig.9).

Estes por sua vez, na América do Sul, são controlados basicamente por três grandes sistemas atmosféricos: a Zona de Convergência Intertropical (ZCIT), responsável pela circulação do litoral mais ao norte do Brasil; o Anticiclone Tropical do Atlântico Sul (ATAS), centro de alta pressão responsável pela origem dos ventos alísios; e Anticiclones Polares Migratórios (APM), centros de alta pressão responsáveis pela passagem dos sistemas frontais.

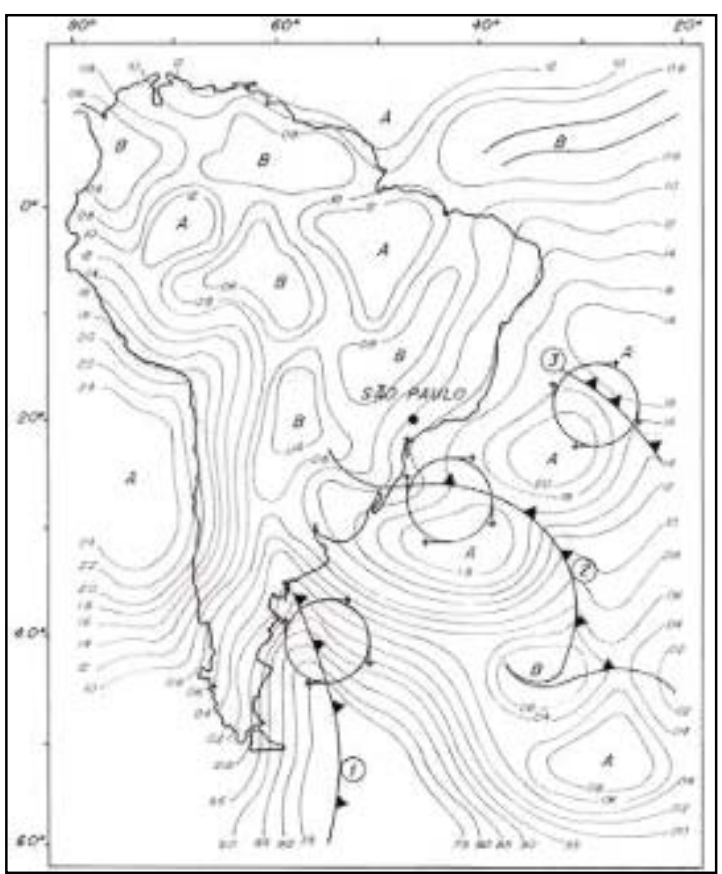

Figura 9 Exemplo da circulação atmosférica sobre a América do Sul. Fonte: METEOROMARINHA apud RODRIGUES (1996).

A ZCIT é um dos mais importantes sistemas meteorológicos que atuam na proximidade do Equador terrestre. Esta é uma 
região de convergência dos ventos alísios de ambos os hemisférios escoando no sentido oeste. Este sistema é responsável pela maior parte da precipitação nas regiões norte e nordeste do país. A ZCIT possui um deslocamento norte - sul ao longo do ano, podendo oscilar entre $14^{\circ} \mathrm{N}$ e $5^{\circ} \mathrm{S}$.

O ATAS é um centro de alta pressão com temperaturas estáveis e relativamente altas associados aos ventos alísios que sopram de NE e E. Estes ventos possuem freqüência constante durante todo 0 ano, variando sua intensidade, entre as latitudes 10 e 40 graus sul. Esta oscilação ocorre junto com as variações sazonais da ZCIT.

Por fim, os APMs são caracterizados por seu deslocamento ao longo da costa sudeste da América do sul, levando massas de ar com temperatura mais baixa de sudeste para nordeste.

Os APMs, em seus deslocamentos, são sempre precedidos por um sistema frontal ou frontogênese. Os sistemas frontais (SFs) são as perturbações atmosféricas de maior importância para o clima do sul e sudeste brasileiro. Estes sistemas frontais se deslocam-se a uma velocidade média de $500 \mathrm{~km} / \mathrm{dia}$, gerando ondas dos quadrantes sudoeste, sul e sudeste que atingem os litorais sul, sudeste e leste do Brasil (BARLETTA, 1997 apud TOZZI, 1999).

0 período de maior ocorrência de sistemas frontais que atingem o litoral leste brasileiro compreende o meio do outono (abril e maio) e o início da primavera (setembro). São observadas, em média, 48 a 54 passagens anuais de sistemas frontais sobre a região. Em qualquer ponto da costa, a passagem frontal é caracterizada, em geral, por condições pré-frontais, atuação frontal e condições pós-frontais, quando o sistema já se deslocou para $\mathrm{NE} / \mathrm{E}$.

Além da ocorrência destes fenômenos de escala sinótica, aponta-se a existência da sazonalidade marcada por características próprias das perturbações e domínio das massas de ar (MARTINS, 2000).

Portanto, em conseqüência da circulação do desenho da costa brasileira pode-se descrever o clima de ondas que atingem o litoral brasileiro por setores, agrupando os trechos onde os sistemas de ondas incidentes apresentam características comuns.

Na costa sul e sudeste brasileira, entre Chuí (RS) e Cabo Frio (RJ), as ondas que atingem a costa são forçadas pelos ventos alísios em boa parte do ano (ondas de NE). Porém, para este setor do litoral, as ondas incidentes com maior capacidade de transporte sedimentar costeiro são as associadas aos sistemas frontais. Estas ondas incidentes dos quadrantes sul e sudeste apresentam em média um período de 10 a 16 segundos e uma altura de 1 a 4 metros.

No setor litorâneo compreendido entre Cabo Frio (RJ) e o estado de Pernambuco, as ondas mais efetivas no transporte sedimentar são predominantemente geradas pelos ventos alísios, dos quadrantes nordeste e leste, com período médio de 5 a $10 \mathrm{se}$ altura entre 1 e $2 \mathrm{~m}$. Eventualmente nos meses de junho a setembro, as ondas originadas por frentes mais ao sul atingem esta parte do litoral brasileiro. Estas ondulações são tipicamente de sul e sudeste, com período médio entre 7 e 12 s e altura de 1 a $2 \mathrm{~m}$.

No trecho entre 0 estado de Pernambuco e 0 cabo do Calcanhar (RN) incidem somente ondas provenientes dos ventos alísios, sem atuação de ondas oriundas da ação de frentes.

Alguns autores subdividem este compartimento litorâneo entre o Cabo Frio (RJ) e o Cabo Calcanhar (RN), pela divisão do segmento costeiro em dois outros segmentos compreendidos emtre Cabo Frio (RJ) e Abrolhos (Ba) e entre Abrolhos (Ba) e Cabo Calcanhar (RN) (MUEHE, 1998). A diferenciação resultaria da maior presença, no primeiro, de ondas formadas pela ação de frentes.

O trecho entre o Cabo Calcanhar (RN) e Oiapoque (AP), apresenta a ação de ventos associados à ZCIT, ou seja, de alísios de rumo SE, que geram ondas de leste e sudeste, com período curto. Nesta região, todo movimento, seja ele na troposfera, no oceano ou nos sedimentos, é direcionado de leste para oeste (MELO, 1983 apud MUEHE, 1998). Outras ondulações oceânicas que incidem neste segmento costeiro são provenientes de tempestades formadas no hemisfério norte. Estas ondas são do tipo marulho, com períodos de até 18 segundos e ocorrem especialmente entre os meses de janeiro e março (inverno no hemisfério setentrional).

\section{Regime de Marés}

A amplitude das marés (a diferença de nível entre a preamar e a baixamar) é um elemento modelador da linha de costa, em função das velocidades de correntes a ela associadas. Estas correntes de marés são significativas no transporte sedimentar costeiro especialmente onde a variação da maré é expressiva.

A maior parte do litoral brasileiro, do estado de Alagoas ao Rio Grande do Sul, apresenta amplitudes de marés inferiores a 2 metros (micromarés). Estas têm importância pontual, apenas onde a geomorfologia propicia um aumento da velocidade da corrente de marés.

Amplitudes superiores a 4 metros (macromarés) ocorrem apenas no estado do Maranhão, em parte do Pará (Salinópolis) e no litoral sul do Cabo Norte (Amapá). Nestes locais as correntes 
de marés possuem capacidade para modificar a morfologia da linha de costa e da plataforma continental interna (Fig. 10). 0 restante do litoral e alguns trechos do litoral da Bahia e Sergipe apresentam mesomarés com amplitudes entre 2 e $4 \mathrm{~m}$.

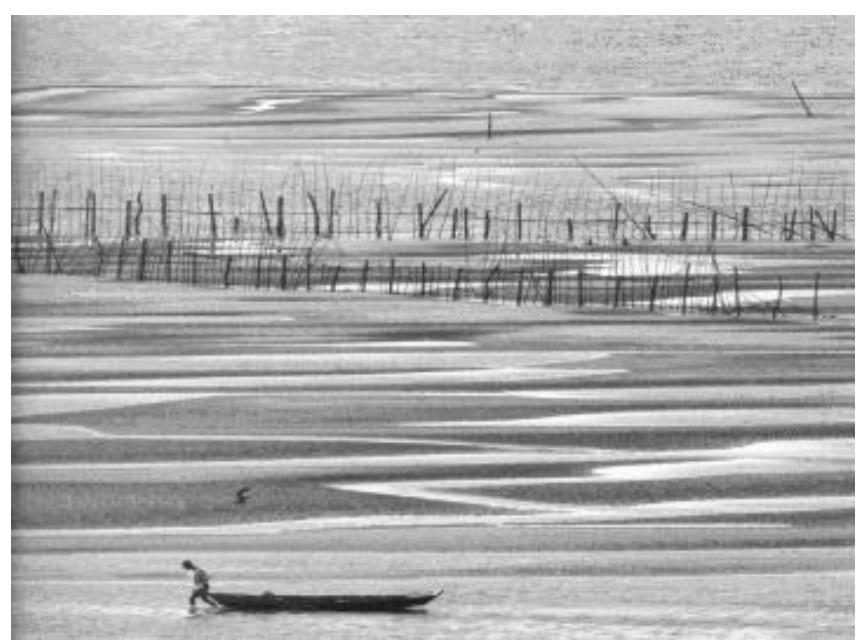

Figura 10 Ambiente de macromarés no Maranhão. Fonte: AB'SABER, 2001.

\section{Compartimentos do Litoral Brasileiro}

A costa brasileira possui uma série de elementos climáticos, oceanográficos e geomorfológicos que condicionam os processos atuantes em determinados trechos do segmento litorâneo brasileiro.

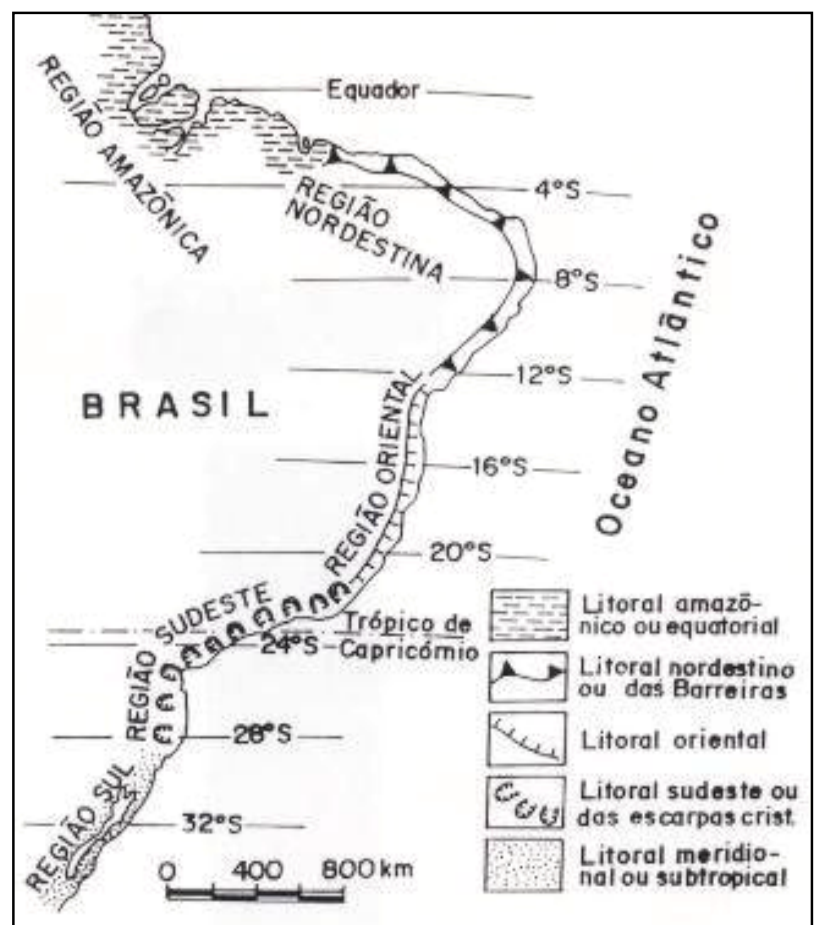

Figura 11 Compartimentos do litoral brasileiro. Fonte: SILVEIRA, 1964.
Com o fim de homogeneizar, compatibilizar e sistematizar as informações de um determinado trecho costeiro, facilitando 0 seu gerenciamento e integração, opta-se muitas vezes pela compartimentação.

No caso da costa brasileira, a divisão clássica em compartimentos, muito utilizada e bem aceita, é a proposta por SILVEIRA (1964), Fig.11. Apesar de não ser um consenso na literatura, possui os limites mais aceitos entre os pesquisadores.

Esta classificação levou em conta parâmetros geomorfológicos, climáticos e oceanográficos. A costa brasileira foi dividida em cinco grandes compartimentos: Litoral Amazônico, Litoral Nordestino de Barreiras, Litoral Oriental, Litoral Sudeste ou de Escarpas Cristalinas e Litoral Meridional ou Subtropical. Os segmentos apresentam as seguintes configurações gerais:

\section{Litoral Amazônico}

O litoral amazônico estende-se entre o extremo norte do Amapá até o Golfão Maranhense, fortemente influenciado pela desembocadura do rio Amazonas (Fig.12). Este segmento costeiro é caracterizado por possuir planícies com até uma centena de quilômetro de largura, consistindo principalmente de terras baixas e freqüentemente inundáveis. Além das terras baixas, ocorrem platôs de sedimentos mais antigos que em vários lugares alcançam o oceano, formando falésias. A plataforma continental também é bastante larga, recoberta de sedimentos lamosos oriundos do rio Amazonas.

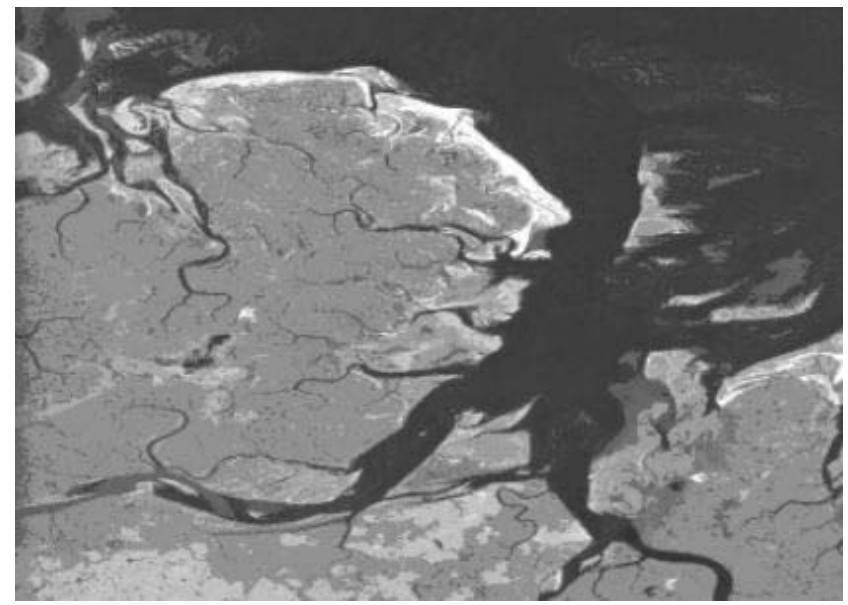

Figura 12 Setor costeiro típico do litoral amazônico. Fonte: Ab'Saber, 2001

\section{Litoral Nordestino ou das Barreiras}

Este segmento do litoral abrange 0 trecho entre a foz do Rio Parnaíba (entre MA e PI) a Salvador (BA), sendo marcado por duas importantes direções de linha de costa (Fig.13). 0 trecho 
compreendido entre o rio Parnaíba e o Cabo São Roque (RN) apresenta direção geral leste-oeste. A direção nordeste-sudeste se estabelece ao sul do Cabo São Roque, sendo que esta mudança de direção na orientação da linha de costa se processa de forma brusca.

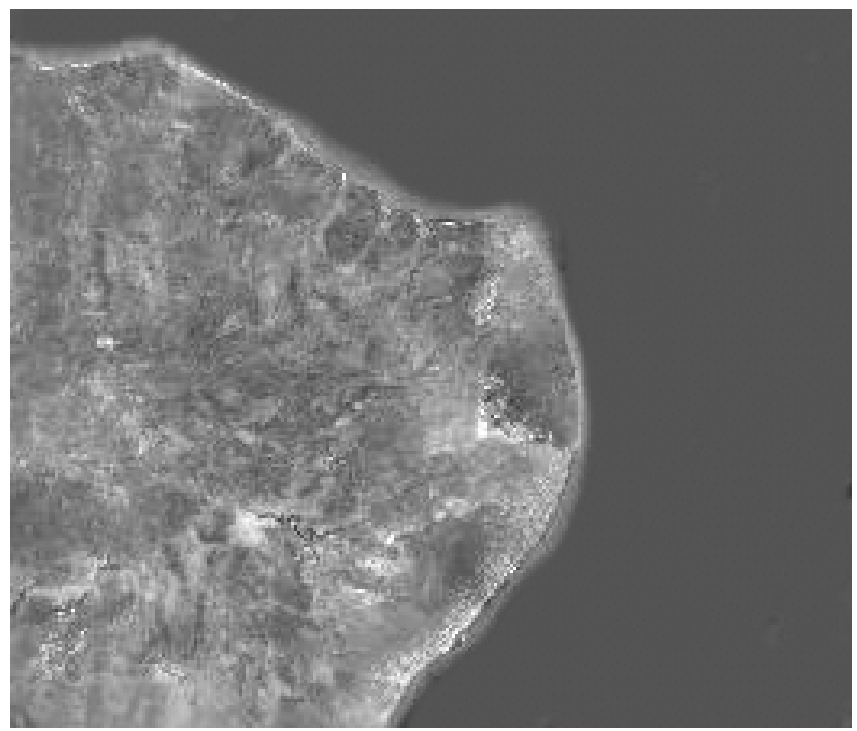

Figura 13 Trecho da costa nordestina brasileira com mudança brusca de direção no Cabo Calcanhar. Fonte: AB'SABER, 2001.

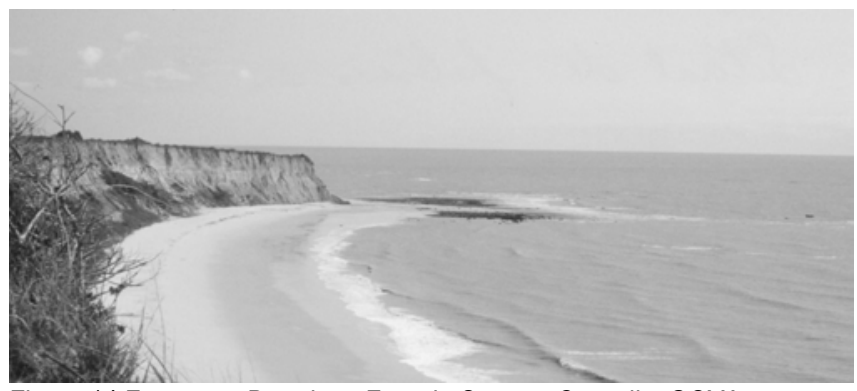

Figura 14 Formação Barreiras. Foto de Samara Cazzoli y GOYA.

A feição mais conspícua neste litoral é a Formação Barreiras (Fig.14). Sedimentar e de idade terciária, ela apresenta um relevo de tabuleiros. Arenitos ou rochas de praias (beach rocks) também são bastante comuns. Neste segmento a plataforma continental é bastante estreita (menos de $80 \mathrm{~km}$ ). A única drenagem (mais pretérita que atual) que exerce alguma influência na dinâmica sedimentar presente é o rio São Francisco. Em sua desembocadura apresenta feição sedimentar em delta.

\section{Litoral Oriental}

Situada entre Salvador (BA) e Cabo Frio (RJ), o litoral oriental é caracterizado por ser uma transição entre os litorais nordestino e sudeste, ou seja, possui elementos dos dois (Fig.15). Exemplo desta mistura de elementos é a presença da Formação Barreiras. Esta se estende, de forma irregular, por todo o litoral, muitas vezes mesclando-se com afloramentos do Embasamento Cristalino. Nas planícies costeiras também estão presentes depósitos sedimentares quaternários bem desenvolvidos, exceto nas imediações da Baía de Todos os Santos (BA).

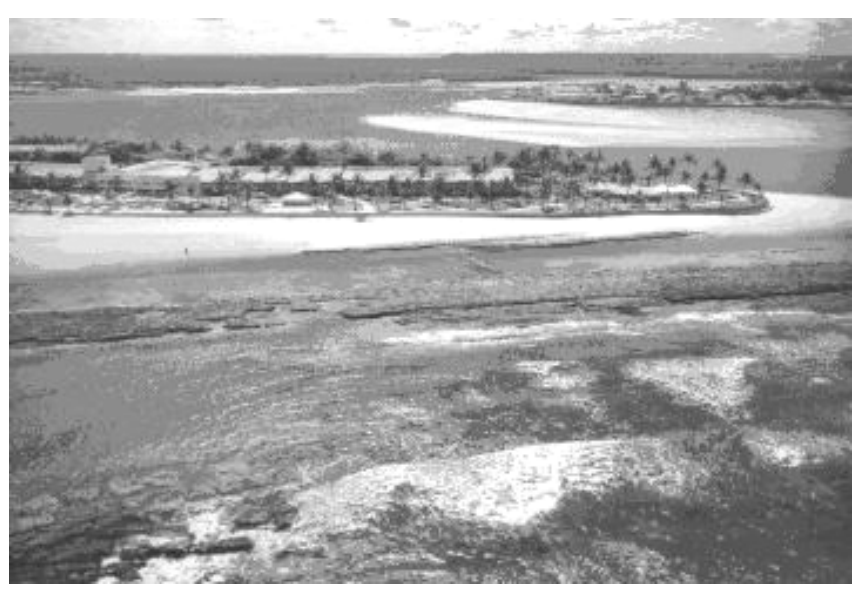

Figura 15 Litoral do Espírito Santo. Fonte: AB'SABER, 2001.

No litoral oriental são também comuns os alinhamentos de recifes de arenitos praiais e de corais. Recifes de corais são também encontrados na região do arquipélago de Abrolhos (BA).

As drenagens são mais numerosas do que as do litoral nordestino. Os rios Contas, Pardo, Jequitinhonha, Doce, Itabapoana e Paraíba do Sul são responsáveis por aporte fluvial mais significativo, construindo planícies costeiras em delta em suas desembocaduras.

A plataforma continental apresenta largura variável com extensões de apenas 30 quilômetros até mais de $200 \mathrm{~km}$, nas áreas de influência dos bancos de Abrolhos e Royal Charlotte.

\section{Litoral Sudeste ou das Escarpas Cristalinas}

Entre Cabo Frio (RJ) e Cabo de Santa Marta (SC), o litoral é caracterizado pela presença da Serra do Mar. Esta é constituída por rochas do Embasamento Cristalino que afloram continuamente neste trecho com alinhamento aproximadamente paralelo à linha de costa (Fig.16).

Uma nova mudança brusca de orientação da linha de costa é verificada na altura de Cabo Frio, onde a direção volta a ser L$O$ até a região da Restinga da Marambaia (RJ). Esta nova orientação está associada à zona de Fratura do Rio de Janeiro. Da baía da Illa Grande até o cabo de Santa Marta, a linha de costa volta a apresentar direção NE-SE. 


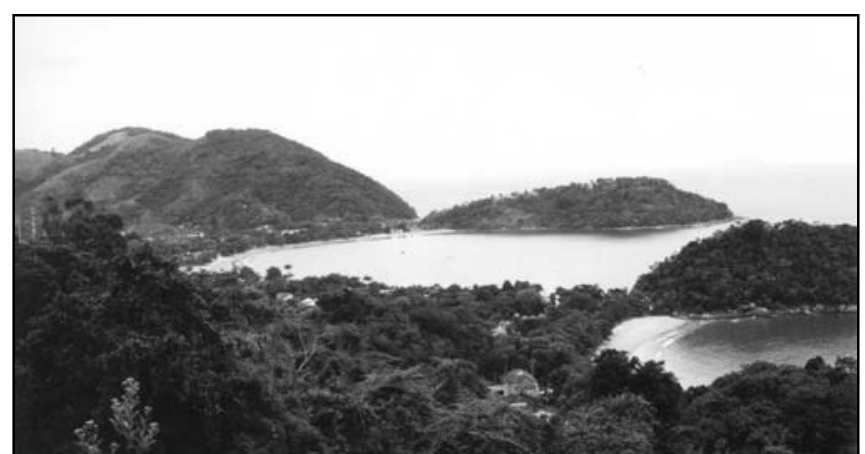

Figura 16 Litoral norte de São Paulo. Foto Samara Cazzoli y Goya.

A maior ou menor distância entre a Serra do Mar e a linha de costa faz com que haja uma grande diversidade de paisagens neste segmento litorâneo, com desenvolvimento de extensas planícies costeiras entre Santos (SP) e a baía de São Francisco do Sul (SC). Ao norte deste ponto e no litoral de Santa Catarina, ao sul da baía de São Francisco, o litoral tende a ser recortado, com vários pontos onde a Serra atinge diretamente a linha de costa. A Serra do Mar também origina diversas baías como a da Guanabara, Ilha Grande, Santos, Paranaguá e São Francisco do Sul.

A maioria das drenagens flui para o interior do continente e não para o oceano, fazendo com que o aporte fluvial neste litoral não seja significativo. Os maiores rios encontrados nesta área são o Ribeira de Iguape e o Itajaí-Açú. A plataforma tem a forma de um grande arco sendo denominado Embaiamento São Paulo.

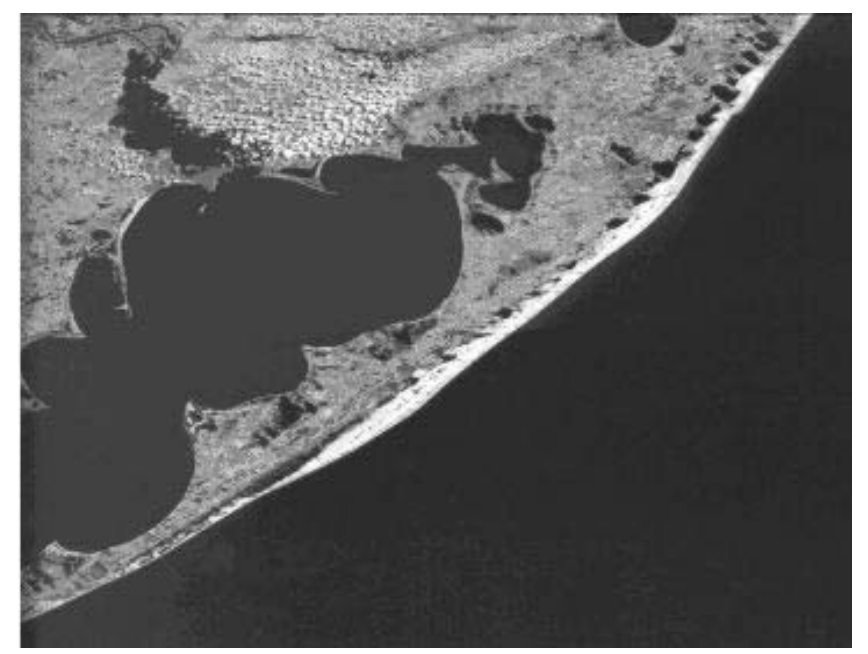

Figura 17 Segmento costeiro do Rio Grande do Sul. Fonte: AB'SABER, 2001.

\section{Litoral Meridional ou Subtropical}

Este segmento litorâneo, que vai do Cabo de Santa Marta
(SC) até o Chuí (RS), é caracterizado por uma linha de costa retilínea, associada a planícies costeiras extensas e arenosas e baixa altitude (Fig.17). A única interrupção deste padrão geral ocorre em Torres (RS), constituída por promontório basáltico junto à atual linha de costa. Outro destaque é a presença de sistemas lagunares bem desenvolvidos associados a campos de dunas.

Não há drenagem significativa que deságüe neste litoral. 0 maior aporte de água doce é a desembocadura da Laguna dos Patos, na altura da cidade de Rio Grande (RS).

A plataforma, por sua vez, é larga, com isóbatas retilíneas, exceto na região de Mostardas (RS) onde há a presença de pequenas depressões e elevações, circulares e alongadas, em posição oblíqua quando comparadas com a linha de costa (FIGUEIREDO Jr, 1975 apud MUEHE, 2001).

\section{Progradação e Erosão}

As linhas de costa do mundo todo, principalmente as costas ligadas a antigas planícies litorâneas, holocênicas e progradantes, como é o caso do litoral brasileiro, estariam em retrogradação (recuo) por perda de areia para as dunas, para a plataforma continental ou para a deriva litorânea (BIRD, 1981).

Atualmente $70 \%$ das costas arenosas do mundo apresentam-se em erosão, 10\% em progradação (avanço) e 20\% sem mudanças significativas (BIRD, 1981). Este predomínio de processos erosivos nas linhas de costa atuais pode estar relacionado a fatores de ação errática ou de forma cumulativa. As variações relativas do nível do mar e as alterações do padrão dinâmico por variações naturais e/ou induzidas pelo homem são os principais fatores.

\section{Variações relativas do nível do mar}

A Regra de BRUUN (1962) propõe que a elevação ou diminuição do nível relativo do mar modifica o equilíbrio de uma zona litorânea (Fig.18). De acordo com esta regra, se ocorrer uma elevação do nível, da escala de tempo secular à geológica, toda a linha de costa estará submetida à ação de processos erosivos até que um novo perfil de equilíbrio seja atingido.

As variações do nível relativo do mar podem ser desencadeadas basicamente por três processos: aqueles associados aos ciclos de glaciação e deglaciação (glacio eustasia), aos eventos de tectônica global (tectono eustasia), e aqueles relacionados às variações da configuração da forma do geóide (geoido eustasia). 


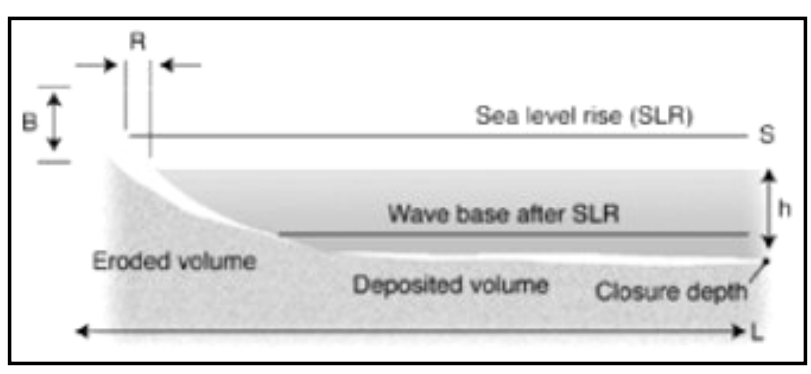

Figura 18 Regra de BRUUN (1962). Fonte: PILKEY e COOPER, 2004.

No caso das costas brasileiras, em escala milenar, apontase a ocorrência de uma regressão marinha a partir de 5100 anos A.P., quando o nível do mar que, nesta época, estava cerca de 4 $\mathrm{m}$ acima do nível atual, retorna ao que se denomina de zero atual (SUGUIO e MARTIN, 1978).

Já em escala secular, com base em análises dos dados maregráficos das estações dos portos de Recife, Rio Grande e da cidade de Cananéia, ao longo dos últimos 50 anos, verificou-se existência de uma variação positiva (ascenção) do nível médio, da ordem de $30 \mathrm{~cm}$ (MESQUITA e LEITE, 1986).

Considerando as informações de escala milenar sobre 0 nível relativo do mar ao longo do litoral leste brasileiro, conclui-se que as costas brasileiras estão em processo de emersão frente a uma tendência franca de regressão marinha. Porém, considerando-se os estudos em escala secular, é possivel identificar uma tendência de elevação do nível marinho, conseqüentemente com as linhas de costas submetidas a processos erosivos.

Aparentemente, os conjuntos de dados avaliados parecem indicar tendências opostas, ou então uma reversão da tendência de variação do nível relativo do mar ao longo do século XX.

As respostas a estas indagações ainda permanecem em aberto. Por um lado, ao menos ao longo da segunda metade do século XX, a ascensão do nível relativo do mar ao longo do litoral brasileiro pode constituir uma causa dos processos erosivos observados em diferentes segmentos costeiros. Por outro, segmentos deste litoral, por vezes próximos de segmentos submetidos à erosão, apresentam processos deposicionais da mesma ordem de grandeza que as áreas contíguas submetidas à erosão.

\section{Mudanças da dinâmica atual por variações naturais}

Os mecanismos de dinâmica costeira essencialmente comandados pela ação dos agentes oceanográficos (ondas, marés e correntes litorâneas) sofrem, por vezes, alterações permanentes ou transitórias, por efeito da ocorrência de eventos episódicos como tormentas, furacões, deslocamentos da foz de rios, desenvolvimentos de deltas, acresção e erosão de bancos arenosos submersos junto às linhas de costa, entre outros.

Ao longo do litoral brasileiro têm sido verificadas perturbações permanentes ou transitórias que acabam por ocasionar variações espaciais das linhas de costas. Por exemplo, vêm sendo verificadas alterações nos ciclos climáticos que determinam as condições de contorno dos parâmetros oceanográficos que afetam o litoral sul e sudeste brasileiro, pela observação de incremento da intensidade das tempestades desde a década de 90 na costa do Rio Grande do Sul (TOZZI, 1999).

Um outro bom exemplo de modificação climática, com reflexos nos processos de dinâmica sedimentar costeira, resultou da passagem do furacão da classe 1 denominado Catarina, entre os dias 27 e 28 de março de 2004. Este foi o primeiro furacão extratropical registrado no Atlântico Sul (Fig.19).

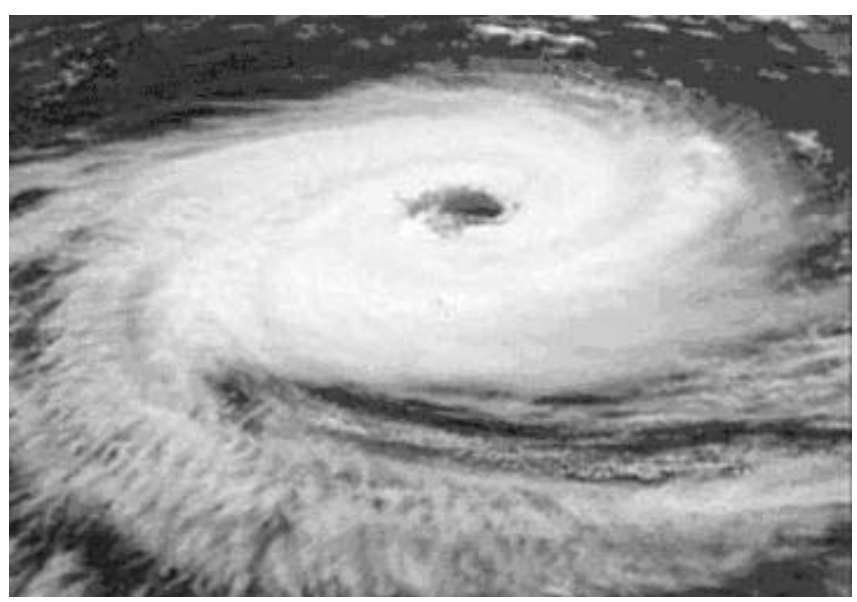

Figura 19 Ciclone Catarina. Fonte: http://www.inpe.br.

\section{Mudanças da dinâmica atual por variações induzidas pela atividade humana}

Há diversos tipos de intervenções antropogênicas que alteram o balanço sedimentar de um segmento costeiro, podendo gerar um déficit de material sedimentar e, conseqüentemente, fenômenos de recuo da linha de costa.

As intervenções mais freqüentes encontradas no litoral brasileiro estão relacionadas ao uso e ocupação do solo ou, mais diretamente, à construção de infra-estrutura urbana, como ruas, calçadas e mesmo residências em regiões ainda sob ação do mar em períodos de tempestades. Há relatos em toda a costa do país de retirada de dunas, de retificações de canais de drenagem e de realização de aterros junto à faixa litorânea. Isto implica em exposição destas obras à ação de ondas em períodos de tempestade. 

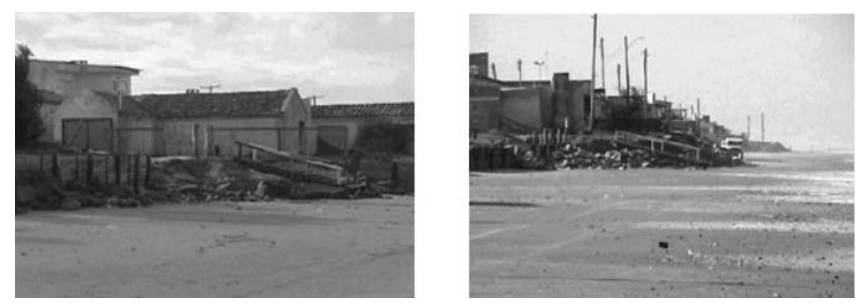

Figura 20 Casas atingidas por tempestades no balneário do Hermenegildo. Fonte: ESTEVES et al., 1999.

Significativo é o caso do Hermenegildo, no litoral sul do Rio Grande do Sul, onde foram edificadas construções para moradia no limite do pós-praia. Quando da passagem de frentes frias geradoras de ondas de altura maior, muitas das edificações são atingidas (ESTEVES et al., 1999). Há relatos de destruição de casas em ruas que antigamente não faziam frente com a orla marinha, mas que hoje se encontram diretamente expostas à ação das ondas de tempestade (Fig.20).

De impacto mais pronunciado e facilmente verificada na costa brasileira é a construção de obras rígidas de engenharia que alteram ou até retém a deriva litorânea de sedimentos arenosos.
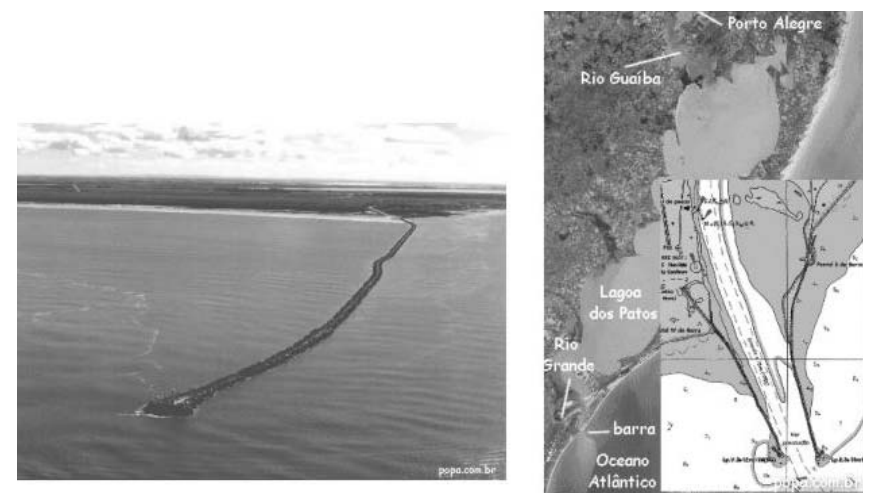

Figura 21 Molhe da barra da Laguna dos patos em Rio Grande com carta batimétrica. Fonte: www.popa.com.br/noticias/acidente_rgrande.htm.

Um exemplo de uma obra rígida, que acaba por alterar a deriva litorânea em um trecho específico da costa gaúcha são os molhes construídos na desembocadura da Laguna dos Patos a fim de facilitar a navegação de entrada e saída da Lagoa (Fig.21). Foram construídos entre 1911 e 1919 e têm cerca de $3,5 \mathrm{~km}$.

Muito comum como solução de engenharia para minimizar processos erosivos pré-existentes, ou mesmo alargar praias para fins turísticos, são pequenos espigões de blocos rochosos (obras rígidas) construídos perpendicularmente à face praial. Exemplos deste tipo de obra podem ser encontrados ao longo de quase todo o litoral brasileiro. Em Caraguatatuba (SP) vários destes espigões foram construídos a fim de deter a erosão que se iniciava por conta da construção da avenida beira-mar (Fig.22).

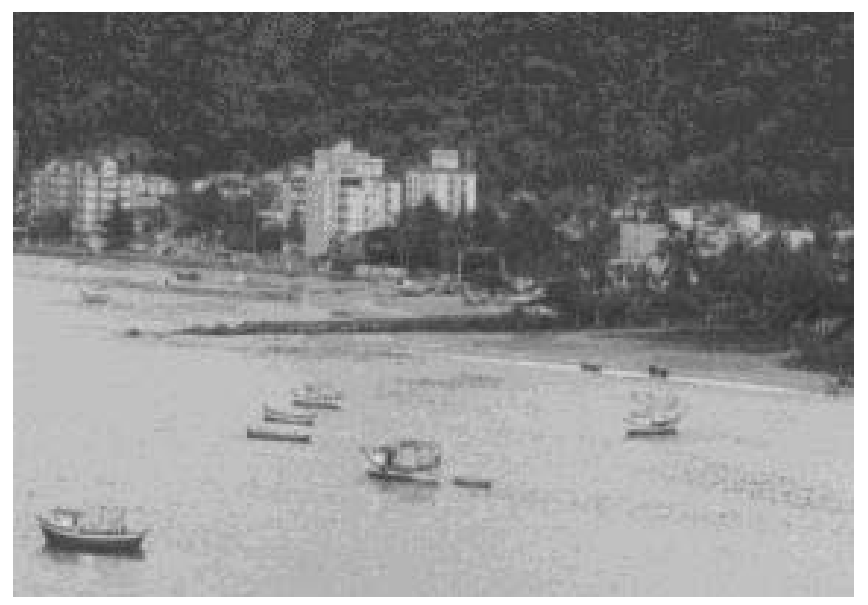

Figura 22 Espigão construído junto à Ponta do Camaroeiro, em Caraguatatuba (SP).

Uma questão que tem acompanhado este tipo de obra quando projetada e implementada inadequadamente é a da retenção do sedimento em um lado do espigão, com a deflagração de erosão no trecho subseqüente, exigindo a construção de um novo espigão e assim sucessivamente.

Uma opção de obra rígida passivel de ser implementada em determinados lugares é a construção sobre pilares vazados. Tem a vantagem de não alterar significativamente o processo de dinâmica sedimentar, pois permite a movimentação pelas correntes de deriva litorânea de grande parte dos sedimentos arenosos, ao longo da faixa litorânea.
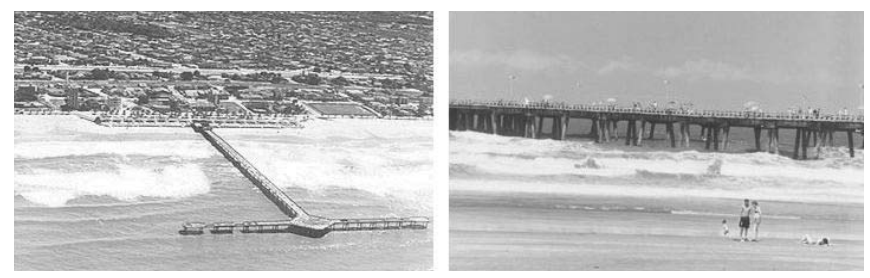

Figura 23 Plataforma de Pesca em Mongaguá, estado de São Paulo. Fonte: www.mongagua.sp.gov.br/mongagua-cidade.htm.

Na década de 70, para a prática da pesca amadora, foi construída sobre pilares uma plataforma de madeira que avança 400 metros mar adentro (plataforma de pesca no bairro de Agenor de Campos, em Mongaguá, SP), sem que a dinâmica sedimentar local tenha sofrido alterações significativas. A estrutura em pilares vazados desta obra altera localmente a morfologia da praia, origi- 
nando bancos de areia pouco mais pronunciados do que os encontrados nos arredores (Fig.23).

Nem todos os tipos de intervenção são realizados diretamente na linha de costa. Muitas vezes alterações efetuadas nos cursos dos rios afetam diretamente o aporte sedimentar para a zona costeira. Exemplos destas intervenções, nas mais diversas escalas de magnitude e tempo, existem por toda a costa brasileira. Porém, digno de nota é a construção de diversas usinas hidrelétricas e reservatórios ao longo do rio São Francisco.

O rio São Francisco é considerado o terceiro maior do país, com cerca de 3000 quilômetros de extensão. A principal fonte de energia da região nordeste conta com usinas hidrelétricas importantes como Sobradinho, Boa Esperança, Paulo Afonso, Itaparica, Três Marias e Xingó (Fig.24).

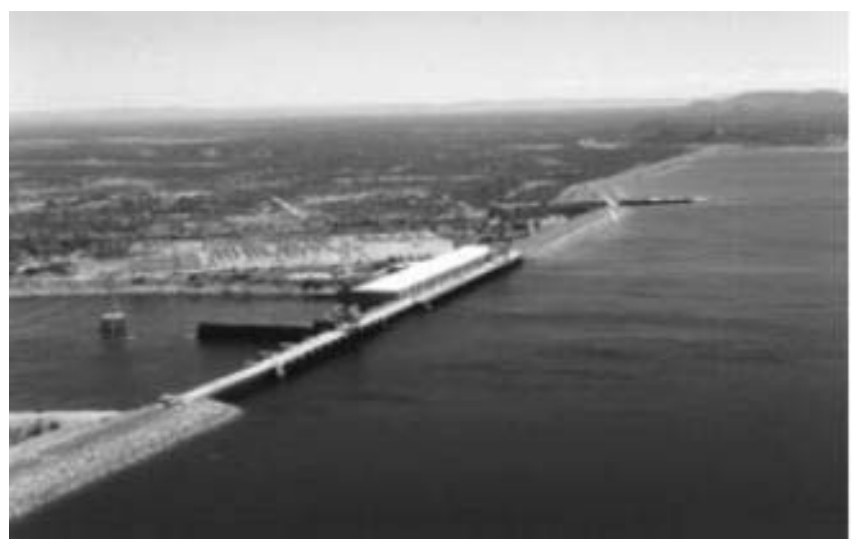

Figura 24 Represa de Sobradinho, no estado da Bahia. Fonte: http:/chesf.gov.br.

Para que se tenha uma idéia de magnitude, dados da Companhia Hidroelétrica do São Francisco (http://chesf.gov.br) indicam que o reservatório de Sobradinho (BA) é o maior lago artificial do mundo, volume de 34 bilhões de $\mathrm{m}^{3}$ com área de 4000 $\mathrm{km}^{2}$, ou seja, 10 vezes maior que a Baía da Guanabara.
Com os represamentos existentes ao longo do canal natural, o aporte sedimentar do rio São Francisco diminuiu muito. Não se tem estimativa precisa de quanto, mas os reflexos já são sentidos em forma de erosão nas praias na região da Vila do Cabeço (SE).

\section{Considerações finais}

Em síntese, a configuração atual do litoral brasileiro é a conjunção das características geomorfológicas resultantes da herança geológica ligada aos eventos de separação gondwânica e afeiçoamento tectônico Mesozóico e Cenozóico da margem continental sul americana e, numa escala de tempo geológica mais restrita (Quaternário), do modelado das planícies costeiras pelas oscilações relativas do nível do mar.

A compartimentação do litoral brasileiro, apresentada por diversos autores (SILVEIRA, 1964; MUEHE, 2001, etc), considera sempre em suas subdivisões as características geomorfológicas e de dinâmica quaternária dos diferentes segmentos costeiros, cujas particularidades e similaridades são respostas às condicionantes evolutivas das áreas de transição entre continente e oceano sul americanos.

Os efeitos erosivos e deposicionais, observados atualmente ao longo de alguns segmentos do litoral brasileiro, têm como causas, além das mudanças do padrão de dinâmica atual por variações naturais (oscilação do nível marinho, alterações dos regimes de ondas e marés associados aos ciclos climáticos), a interferência humana sobre os mecanismos de dinâmica costeira.

A partir de toda esta explanação de condições que influenciam o processo sedimentar do litoral brasileiro, fica a grande questão: como compatibilizar o uso e ocupação do litoral na escala de tempo humana com as tendências evolutivas naturais verificadas na escala de tempo geológica? Esta é uma resposta que ninguém por enquanto pode esclarecer totalmente, mas será crucial que a sociedade esteja atenta a ela. 
TESSLER, M.G.; GOYA, S.C. (2005). Conditioning factors of coastal processes in the Brazilian Coastal Area. Revista do Departamento de Geografia, n. 17, p. 11-23.

Abstract: This text approaches the action of the existing processes on the Brazilian coast considered as conditioning agents. It starts with the study of the geologic legacy, the variation of sea level and the modelling of coastal plains by the action of longshore currents. Further, the Brazilian coast partition is studied, describing the different coastal segments in a summarized way. Finally, the coastal erosion issue is discussed. This process presents natural and antrophogenic causes where both are considered, by evaluating some cases along the Brazilian coast. As conclusion, it is made a brief description about compatibility between geologic and historical evolutions of the coastal environments created throughout the coast occupation.

Key words: Coastal Systems; Actual Coast Dynamics; Geological Legacy; Variation of Sea Level.

Recebido em 7 de setembro de 2005, aceito em 2 de outubro de 2005.

\section{Referências}

ALMEIDA, F.F.M. (1976) The system of continental rifts bordering the Santos basin, Brazil. Anais da Academia Brasileira de Ciências, 48 (suplemento): 15-26.

ALMEIDA, F.F. M.; CARNEIRO, C.D.R. (1987) Magmatic occurrences of post-permian age of South America platform. Boletim IG-USP, Série Científica, 20: 71-85.

AB'SABER, A.N. (2001) Litoral do Brasil. Metalivros, São Paulo.

BIGARELLA, J. J. (1965) Subsídios para o estudo das variações do nível oceânico no Quaternário Brasileiro. Anais da Academia Brasileira de Ciências, 37 (suplemento): 263-278.

BIRD, E.C.F. (1981) Recent changes on the world's sandy shorelines. In: BIRD, E.C.F \& KOIKE, K. (eds). Coastal dynamics and scientific sites: 5-30. Departament of Geography, Kowazawa University, Japan.

BITTENCOURT, A.C.S.P.; MARTIN, L.; VILAS-BOAS, G.S.; FLEXOR, J.M. (1979) Quaternary marine systems formations of the State of Bahia, Brazil. In: International Symposium on Coastal Evolution in the Quaternary. São Paulo. Proceedings. IGCP Projetc 61: 232-253.

BRANNER, J.C. (1904) The stone reefs of Brazil, their geological and geographical relations. Bulletin of Museum of Comparative Zoology, 44: geological series 7 .

BRUUN, P. (1962) Sea level rise as a cause of shore erosion. Journal of Wyareways and Harbors Division, 88: 117 - 130.

ESTEVES, L.S.; VRANJAC, M.P.; BARLETTA, R.C.; M.A.G. PIVEL; ERTHAL, S.; VANZ, A.; SILVA, A.R.P.; OLIVEIRA, U.R. (1999) Impacto de um evento de alta energia nas obras de proteção costeira no balneário do Hermenegildo, RS, Brasil. In: Anais do VII Congresso da ABEQUA. VII Congresso da ABEQUA, 1999, Porto Seguro.
FREITAS, R.O. (1951) Ensaio sobre a tectônica moderna do Brasil. Boletim da Faculdade de Filosofia, Ciências e Letras, série Geologia, 130: 120p.

HARTT, C.F. (1870) Geology and Physical Geography of Brazil. Boston Fields, Osgood \& Co., 620p.

MARTINS, C.C. (2000) Variações morfológicas e sedimentares de curto período em perfis praiais, praia de Bertioga/SP. Dissertação de Mestrado, Universidade de São Paulo, Instituto Oceanográfico. 191p.

MESQUITA, A.; LEITE, J.B.A. (1986) Sobre a Variabilidade do Nível Médio do Mar na costa Sudeste do Brasil. Revista. Brasileira de Geofisica, (4 ):229-236.

MUEHE, D. (1998) Estado morfodinâmico praial no instante da observação: uma alternativa de identificação. São Paulo, Revista Brasileira de Oceanografia, 46 (2): 157-169.

MUEHE, D. (2001) $O$ litoral brasileiro e sua compartimentação. In: CUNHA, S.B.; GUERRA, A.J.T. 2001. Geomorfologia do Brasil. Editora Bertrand Brasil, 2a edição, Rio de Janeiro. 273349.

PILKEY, O.H.; COOPER, A.G. (2004) Society and Sea Level Rise. Science, 19 (303): 1781-1782.

PONTE, F.C.; ASMUS, H.E. (1978) Geological framework of the Brazilian continental margin. Geologische Rundschau, 67: 235.

RODRIGUES, M. (1996) Sedimentação atual nas enseadas de Ubatumirim e Picinguaba e Plataforma Interna adjacente, Ubatuba, Estado de São Paulo. Dissertação de Mestrado. Universidade de São Paulo, Instituto Oceanográfico. 158p.

SILVEIRA, J.D. (1964) Morfologia do litoral. In: Azevedo, A. (ed). Brasil: a terra e o homem. Companhia Editora Nacional, São Paulo.Volume 1: 253-305. 
SUGUIO, K.; MARTIN, L. (1978) Formações quaternárias marinhas do litoral paulista e sul fluminense (Quaternary marine formations of the State of São Paulo and southern Rio de Janeiro). In: Internacional Symposium on Coastal Evolution in the Quaternary, São Paulo, 1978. São Paulo, SBG/IGUSP, Special Publication, nㅡ 1, 55p.

SUGUIO, K.; MARTIN, L.; BITTENCOURT, A.C.S.P.; DOMINGUES, J.M.L.; FLEXOR, J.M.; AZEVEDO, A.E.G. (1985) Flutuações do nível relativo do mar durante 0 Quaternário Superior ao longo do litoral brasileiro e suas implicações na sedimentação costeira. Revista Brasileira de Geociências, 15 (4): 273-286.
SUGUIO, K.; MARTIN, L.; FLEXOR, J. M. (1988) Quaternary sealevels of the Brazilian coast: recent progress. Episodes, 11: 203-208.

TOZZI, H.A.M. (1999) Influência das tempestades extratropicais sobre o estoque subaéreo das praias entre Rio Grande e Chuí, RS. Campanha de outono e inverno de 1996. Dissertação de Mestrado. UFRS/ CECO.

VILLWOOCK, J.A.; TOMAZELLI, J.L.; LOSS, E.L.; DEHNHARDT, E.A.; HORN FILHO, N.O.; BACHI, F.A.; DEHNHARDT, B.A. (1986) Geology of the Rio Grande do Sul Coastal Province. In: RABASSA, J. (ed.). Quaternary of South America and Antartic Peninsula, 4: 79-94. 